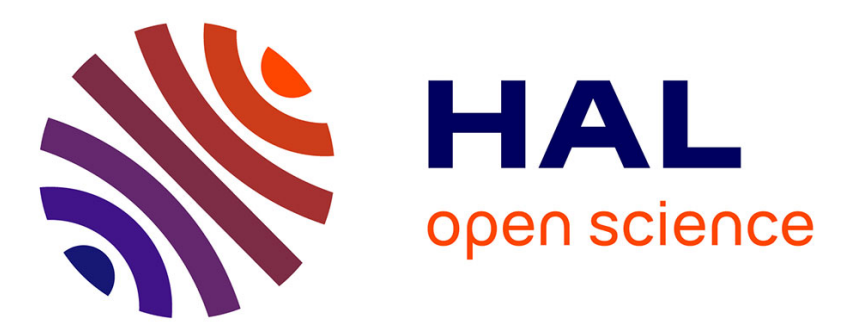

\title{
Pharmacological profile of engineered 5-HT4 receptors and identification of 5-HT4 receptor-biased ligands
}

Florence Gaven, Lucie P. Pellissier, Emilie Queffeulou, Maud Cochet-Bissuel, Joël Bockaert, Aline Dumuis, Sylvie Claeysen

\section{- To cite this version:}

Florence Gaven, Lucie P. Pellissier, Emilie Queffeulou, Maud Cochet-Bissuel, Joël Bockaert, et al.. Pharmacological profile of engineered 5-HT4 receptors and identification of 5-HT4 receptor-biased ligands. Brain Research, 2013, 1511, pp.65-72. 10.1016/j.brainres.2012.11.005 . hal-02482146

\author{
HAL Id: hal-02482146 \\ https://hal.science/hal-02482146
}

Submitted on 17 Feb 2020

HAL is a multi-disciplinary open access archive for the deposit and dissemination of scientific research documents, whether they are published or not. The documents may come from teaching and research institutions in France or abroad, or from public or private research centers.
L'archive ouverte pluridisciplinaire HAL, est destinée au dépôt et à la diffusion de documents scientifiques de niveau recherche, publiés ou non, émanant des établissements d'enseignement et de recherche français ou étrangers, des laboratoires publics ou privés. 


\title{
Pharmacological profile of engineered 5-HT 4 receptors and identification of $5-\mathrm{HT}_{4}$ receptor-biased ligands ${ }^{1}$
}

\author{
Florence Gaven ${ }^{\dagger, a b c}$, Lucie P. Pellissier ${ }^{\dagger, a b c}$, Emilie Queffeulou ${ }^{\text {abc }}$, Maud Cochet $^{\text {abc }}$, Joël \\ Bockaert $^{\text {abc }}$, Aline Dumuis ${ }^{\text {abc }}$ and Sylvie Claeysen ${ }^{*}$,abc
}

${ }^{a}$ CNRS, UMR-5203, Institut de Génomique Fonctionnelle, F-34000 Montpellier, France

${ }^{\mathrm{b}}$ Inserm, U661, F-34000 Montpellier, France

${ }^{c}$ Universités de Montpellier 1 \& 2, UMR-5203, F-34000 Montpellier, France

${ }^{*}$ Corresponding author: Sylvie Claeysen, Institut de Génomique Fonctionnelle, 141 Rue de la Cardonille, 34094 Montpellier Cedex 5, France. Phone: +33 4343592 15; Fax: +33 4675424 32; Email: sylvie.claeysen@igf.cnrs.fr

†These authors contribute equally to the work.

\begin{abstract}
G protein-coupled receptors (GPCRs) can activate simultaneously multiple signaling pathways upon agonist binding. The combined use of engineered GPCRs, such as the Receptors Activated Solely by Synthetic Ligands (RASSLs), and of biased ligands that activate only one pathway at a time might help deciphering the physiological role of each $G$ protein signaling. In order to find serotonin type 4 receptor $\left(5-\mathrm{HT}_{4} \mathrm{R}\right)$ biased ligands, we analyzed the ability of several compounds to activate the $\mathrm{G}_{\mathrm{s}}$ and $\mathrm{G}_{\mathrm{q} / 11}$ pathways in COS-7 cells that transiently express wild type 5- $\mathrm{HT}_{4} \mathrm{R}$, the 5-HT $\mathrm{H}_{4} \mathrm{R}-\mathrm{D}{ }^{\text {mo }} \mathrm{A}$ mutant (known also as 5-HT $-\mathrm{RASSL}$, or Rs1) or the $5-\mathrm{HT}_{4} \mathrm{R}-\mathrm{T}^{104} \mathrm{~A}$ mutant, which modifies agonist-induced $5-\mathrm{HT}_{4} \mathrm{R}$ activation. This analysis allowed completing the pharmacological profile of the two mutant 5$\mathrm{HT}_{4} \mathrm{Rs}$, but we did not find any biased ligand for the mutant receptors. Conversely, we identified the first biased agonists for wild type 5- $\mathrm{HT}_{4} \mathrm{R}$. Indeed, RS 67333 and prucalopride acted as partial agonists to induce cAMP accumulation, but as antagonists on inositol phosphate production. Moreover, they showed very different antagonist potencies that could be exploited to study the activation of the $G_{s}$ pathway, with or without concomitant block of $G_{q / 11}$ signaling.
\end{abstract}

Keywords: 5-HT $\mathrm{HT}_{4}$ receptor; $\mathrm{G}$ protein-coupled receptor; biased ligand; cyclic AMP, inositol phosphate.

\footnotetext{
${ }^{1}$ Abbreviations: RASSL, Receptor Activated Solely by Synthetic Ligand; DREADD, Designer Receptors Exclusively Activated by Designer Drugs; $5-\mathrm{HT}_{4} \mathrm{R}$, serotonin type 4 receptor.
} 


\section{HIGHLIGHTS}

- We tested the major 5-HT $\mathrm{R}$ ligands with WT, D ${ }^{\cdots A}$ and T ${ }^{\cdots} \mathrm{A}$ 5-HT $\mathrm{Rs}$.

- We examined 5-HT R-induced $\mathrm{G}_{\mathrm{s}}$ and $\mathrm{G}_{q 11}$ activation.

- We measured cAMP and inositol phosphate accumulation upon 5-HT $\mathrm{R}^{\mathrm{R}}$ activation.

- We identified molecules that activate the $\mathrm{G}_{s}$ but not the $\mathrm{G}_{q 11}$ pathway.

- We identified the first biased 5-HT_R ligands: RS 67333 and prucalopride. 


\section{Introduction}

G protein-coupled receptors (GPCRs) convert extracellular messages into intracellular signals to trigger the appropriate cellular responses. As GPCRs can induce multiple pathways at the same time (Rajagopal et al., 2010), it is very difficult to decipher the consequences of the activation of a precise $\mathrm{G}$ protein in a physiological context. To overcome this problem, different GPCRs have been engineered over the last decade. First, Receptors Activated Solely by Synthetic Ligands (RASSLs) were generated by site-directed mutagenesis and $\mathrm{G}_{\mathrm{q}^{-}}, \mathrm{G}_{\mathrm{s}}$ - and $\mathrm{G}_{\mathrm{i}}$-coupled RASSLs are now available (Conklin et al., 2008; Coward et al., 1998; Scearce-Levie et al., 2001). These GPCRs are insensitive to their endogenous ligand and can be activated only by specific synthetic ligands. Then, Designer Receptors Exclusively Activated by Designer Drugs (DREADDs) were produced (Dong et al., 2010) by artificially evolving the $\mathrm{M}_{3}$ and $\mathrm{M}_{4}$ muscarinic receptors to respond only to a silent drug (clozapine$\mathrm{N}$-oxide, CNO), and not to their endogenous ligand acetylcholine (Armbruster et al., 2007). A panel of DREADDs was thus created to control all the G-protein signaling pathways (Conklin et al., 2008). Moreover, as GPCRs bind not only to G proteins but also to arrestin family members, the group of J. Wess developed recently an arrestin-biased DREADD (Nakajima and Wess, 2012).

We engineered the first $\mathrm{G}_{\mathrm{s}}$-coupled RASSL, derived from the serotonergic type 4 receptor $\left(5-\mathrm{HT}_{4} \mathrm{R}\right)$, about ten years ago (Claeysen et al., 2003). This RASSL was obtained by mutating a single aspartate residue $\left(\mathrm{D}^{100}\right)$ in the transmembrane domain 3 of $5-\mathrm{HT}_{4} \mathrm{R}$, a residue that is well conserved in GPCRs and particularly in biogenic amine receptors. The $5-\mathrm{HT}_{4} \mathrm{R}-\mathrm{D}^{100} \mathrm{~A}$ mutant has lost the ability to bind to serotonin (5-hydroxytryptamine; 5-HT); however, it can be fully activated by a wide variety of highly specific 5- $\mathrm{HT}_{4} \mathrm{R}$ agonists (Claeysen et al., 2003). Later, we identified a secondary coupling of 5- $\mathrm{HT}_{4} \mathrm{R}$ to the $\mathrm{G}_{\mathrm{q} / 11}$ pathway, leading to inositol 3-phosphate ( $\mathrm{IP}_{3}$ ) production (Barthet et al., 2007). Therefore, in collaboration with B. Conklin's group, we optimized the $5-\mathrm{HT} R-\mathrm{D}^{100} \mathrm{~A}$ mutant by inserting the additional point mutation $\mathrm{D}^{\star} \mathrm{N}$ or $\mathrm{D}^{\oplus \mathrm{A}}$ that suppresses 5 -HT $\mathrm{H}$-induced $\mathrm{IP}_{3}$ production, in order to obtain a pure $\mathrm{G}_{\mathrm{s}}$-coupled receptor (Chang et al., 2007).

Biased agonism has been described for many GPCRs. Indeed, a wide range of ligands can promote different signaling events downstream of a particular GPCR (Gesty-Palmer et al., 2006; Rajagopal et al., 2010; Thomsen et al., 2012; Wei et al., 2003). A ligand that acts as an agonist for one pathway can behave as an antagonist, an inverse agonist or be without effect on the secondary pathway engaged by the same GPCR. We hypothesized that 5-HTR ligands that could differentially activate $\mathrm{G}_{\mathrm{s}}$ and $\mathrm{G}_{\mathrm{q} / 11}$ could help deciphering the roles of these different signaling pathways and could also represent new ligands for RASSLs. Thus, from a wide panel of potential 5-HT $\mathrm{R}$ ligands we selected 22 compounds that belong to different chemical classes in order to cover almost all the different $5-\mathrm{HT}_{4} \mathrm{R}$ ligand families. We then assessed whether these compounds could induce cAMP production upon activation by wild type 5-HT $\mathrm{H}_{4} \mathrm{R}$ (WT), the $5-\mathrm{HT}_{4} \mathrm{R}-\mathrm{D}{ }^{œ \mathrm{~A}}$ mutant (5-HT ${ }_{4} \mathrm{R}-\mathrm{RASSL}$ or Rs1) (Claeysen et al., 2003) 
or the $5-\mathrm{HT}_{4} \mathrm{R}-\mathrm{T}^{10} \mathrm{~A}$ mutant (the $\mathrm{T}^{104} \mathrm{~A}$ mutation modifies agonist-induced $5-\mathrm{HT}_{4} \mathrm{R}$ activation) (Pellissier et al., 2009)). We then measured the ability of 10 of these compounds to induce $\mathrm{IP}_{3}$ production by quantifying $\mathrm{IP}_{1}$ accumulation. Finally, we thoroughly characterized the two more interesting 5-HT $\mathrm{R}_{4}$-biased ligands.

\section{Results}

\subsection{Pharmacological screening of the functional coupling between 5-HT,R ligands and WT 5-} HT، R, 5-HT,R-D ${ }^{10 A}$ or 5-HT,R-T ${ }^{104} A$

To identify $5-H_{T} R$ ligands that could differentially activate $\mathrm{G}_{\mathrm{s}}$ and $\mathrm{G}_{\mathrm{q} / 11}$, COS cells were transiently transfected with the WT 5-HT ${ }_{4(\mathrm{a})} \mathrm{R}, 5-\mathrm{HT}_{4} \mathrm{R}-\mathrm{D}^{100} \mathrm{~A}$ or $5-\mathrm{HT}_{4} \mathrm{R}-\mathrm{T}^{104} \mathrm{~A}$ cDNA plasmids (100 ng cDNA / $10^{7}$ cells, corresponding to $9.5 \pm 0.9,9.2 \pm 0.7$ and $8.7 \pm 0.6 \mathrm{pmol} / \mathrm{mg}$ proteins, respectively). Cells were then incubated with each ligand and cAMP and $\mathrm{IP}_{1}$ (a breakdown product of $\mathrm{IP}_{3}$ ) accumulation were quantified using the specific CisBio HTRF kits (see Experimental Procedures). The maximal responses above basal (expressed as percentage of BIMU8 maximal response) are summarized in Tables 1-3. Supplementary Figure 1 shows the raw data in which the basal cAMP or $\mathrm{IP}_{1}$ accumulation was not subtracted.

\subsection{1. cAMP accumulation}

As previously described, cAMP accumulation was more strongly induced following binding of 5$\mathrm{HT}_{4} \mathrm{R}$ agonists to 5-HT R-D ${ }^{\cdots} \mathrm{A}$ than to WT 5-HT, R, except for 5-HT and related molecules that belong to the indole class, such as HTF919 (Claeysen et al., 2003) (Table 1 and Supplemental Figure 1B). Conversely, signaling transduction through $5-\mathrm{HT}, \mathrm{R}-\mathrm{T}^{104} \mathrm{~A}$ resulted in reduced activation of cAMP production, except with the 5- $\mathrm{HT}_{4} \mathrm{R}$ agonists of the indole class (5-HT, HTF919) and the benzimidazolones (BIMU1 and BIMU8) (Table 1 and Supplemental Figure 1B).

Compounds that are classically described as $5-\mathrm{HT}_{4} \mathrm{R}$ antagonists or weak, partial agonists acted as partial agonists (GR 113808, GR 125487, for example) or even as full agonists (ML10375, SB 204070) when coupled to 5-HTR-D ${ }^{\cdots 0}$ (Table 2 and Supplemental Figure 1A). Inverse agonists, such as RO 1162617 or RO 116 1148, behaved as neutral antagonists when interacting with this RASSL. Antagonists and inverse agonists did not activate cAMP production via $5-\mathrm{HT}$ R- $\mathrm{T}^{104} \mathrm{~A}$. Tropisetron, which acts as a $5-\mathrm{HT}_{4} \mathrm{R}$ antagonist or week partial agonist, was the only drug that retained some activity with the $\mathrm{T}^{104} \mathrm{~A}$ mutant (Table 2 and Supplemental Figure 1A). 


\subsection{2. $\mathrm{IP}_{1}$ accumulation}

Receptor-induced $\mathrm{IP}_{1}$ accumulation (Table 3 and Supplemental Figure 1C) was assessed using nine compounds that were classified as 5- $\mathrm{HT}_{4} \mathrm{R}$ agonists based on their ability to induce cAMP accumulation and ML 10375 that acts as a 5- $\mathrm{HT}_{4} \mathrm{R}$ antagonist. Dose-response curves were generated to analyze precisely the $\mathrm{G}_{q 1}$ activation profiles (Figure 1). For WT 5-HT $\mathrm{R}$, the $\mathrm{EC}_{50}$ values of all the tested ligands were shifted to the right compared to $\mathrm{G}_{\mathrm{s}}$ activation (for instance, 5-HT EC $\mathrm{EC}_{50}=4.2 \pm 0.8 \mathrm{x}$ $10{ }^{\circ} \mathrm{M}$ for cAMP production and $1.9 \pm 0.3 \times 10 \cdot \mathrm{M}$ for $\mathrm{IP}_{1}$ accumulation) (Tables 1,3 ). Molecules of the indole class (5-HT, HTF919) and benzimidazolones (BIMU8) were the most potent and effective activators of the $\mathrm{G}_{q 11}$ pathway via WT 5-HTR (Figure 1A, B). The $\mathrm{G}_{q \| 1}$ activation pattern following coupling of 5-HT R-D ${ }^{\circ 0} \mathrm{~A}$ with the different ligands was comparable to the $\mathrm{G}_{\mathrm{s}}$ activation profile obtained for the same molecules (Figure 1C, D and Supplementary Figure 1B, C). Indeed, the majority of the tested compounds could induce $\mathrm{IP}_{1}$ accumulation upon 5-HT $\mathrm{R}-\mathrm{D}{ }^{\cdots} \mathrm{A}$ stimulation, except molecules belonging to the indole class (5-HT, HTF919). Similarly, RS 67333 was much less efficient in stimulating $\mathrm{G}_{q 11}$ signaling than in activating $\mathrm{G}_{s}$ via $5-\mathrm{HT}_{4} \mathrm{R}-\mathrm{D}^{10} \mathrm{~A}$ (Table1). Finally, $5-\mathrm{HT}_{4} \mathrm{R}-\mathrm{T}^{104} \mathrm{~A}$ could stimulate $\mathrm{IP}_{1}$ production only very weakly (Figure 1E, F and Supplemental Figure 1C) and ML 10302 acted as an inverse agonist with this receptor mutant (Table1, Figure 1F and Supplemental Figure 1C).

\subsection{Characterization of biased ligands for WT $5-H T, R$}

The results of the functional screening indicated that, among the tested compounds, RS 67333, prucalopride and ML 10302 acted as partial agonists for the $\mathrm{G}_{\mathrm{s}}$ pathway and induced only weakly $\mathrm{IP}_{1}$ accumulation following interaction with WT $5-\mathrm{HT}_{4} \mathrm{R}$ (Figure 2A, B and C). Specifically, doseresponse curves showed that the $\mathrm{EC}_{50}$ values for RS 67333-mediated $\mathrm{G}_{\mathrm{g} / 11}$ activation were strongly shifted to the right in comparison to those concerning $\mathrm{G}_{\mathrm{s}}$ activation $\left(\mathrm{EC}_{50}=8.4 \pm 1.1 \times 10^{-10} \mathrm{M}\right.$ for cAMP and $2.0 \pm 0.7 \times 10^{-7} \mathrm{M}$ for $\mathrm{IP}_{1}$ accumulation) with a significant loss of efficacy (from $49 \pm 2 \%$ for cAMP to $19 \pm 1 \%$ for $\mathrm{IP}_{1}$ accumulation at $10^{-5} \mathrm{M}$ ) (Figure $2 \mathrm{C}$ and Tables 1 and 3). Prucalopride and ML 10302 could not induce $\mathrm{IP}_{1}$ accumulation (Figure 2B, C and Table 3).

In competition experiments, RS 67333 could efficiently inhibit BIMU8-induced $\mathrm{IP}_{1}$ accumulation with an $\mathrm{IC}_{50}$ of $3.4 \pm 0.8 \times 10^{-9} \mathrm{M}$, similar to the $\mathrm{IC}_{50}$ of $\mathrm{GR} 113808\left(3.8 \pm 1.1 \times 10^{-9} \mathrm{M}\right)$ (Figure 2D). However, RS 67333 could not completely reverse IP ${ }_{1}$ production, as this drug possesses a weak partial agonist activity towards the $\mathrm{G}_{\mathrm{q} / 11}$ pathway (Figure $2 \mathrm{~B}, \mathrm{D}$ ). Prucalopride was much less potent than $\mathrm{RS}$ 67333 in competing with BIMU8-induced $\mathrm{IP}_{1}$ accumulation $\left(\mathrm{IC}_{50}=6.2 \pm 1.7 \times 10^{-6} \mathrm{M}\right.$ ) (Figure 2D). Finally, the efficacy bias factor (eBF) was calculated as the ratio between the maximal response $\left(\mathrm{R}_{\max }\right)$ of the two signaling pathways (cAMP/ $\mathrm{IP}_{1}$ ratio), as described by $\mathrm{H}$. Bräuner-Osborne's group (Thomsen et al., 2012). Taking BIMU8 as the reference, the eBF for 5-HT and HTF919 were $1.1 \pm 0.2$ and $0.9 \pm 0.1$, respectively, whereas the eBF value for RS 67333 was $2.6 \pm 0.3$. 


\section{Discussion}

In order to find pharmacological tools to decipher the role of the different $G$ protein-linked signaling pathways engaged by $5-\mathrm{HT}_{4} \mathrm{R}$, we tested the ability of several specific compounds to induce cAMP and $\mathrm{IP}_{1}$ accumulation following coupling with wild type $5-\mathrm{HT}_{4} \mathrm{R}$ and with two previously described receptor mutants $\left(5-\mathrm{HT}_{4} \mathrm{R}-\mathrm{D}{ }^{\cdots \mathrm{A}} \mathrm{A}\right.$ and $\left.-\mathrm{T}^{104} \mathrm{~A}\right)$. Our results confirm that a wide range of ligands stimulate more efficiently 5- $\mathrm{HT}_{4}-\mathrm{D}^{\mathrm{io}} \mathrm{A}$ - than WT 5-HT $\mathrm{HT}_{4} \mathrm{R}$-mediated signaling; however, we could not identify a molecule that selectively activates only $\mathrm{G}_{\mathrm{s}}\left(\right.$ and not $\mathrm{G}_{\mathrm{q} / 11}$ ) upon stimulation of $5-\mathrm{HT}_{4}-\mathrm{D}^{œ \mathrm{~A}}$ or of 5$\mathrm{HT}_{4} \mathrm{R}-\mathrm{T}^{104} \mathrm{~A}$. ML 10302 was the only drug that acted as a weak partial agonist for the WT receptor, a full agonist for the $\mathrm{D}^{\infty} \mathrm{A}$ mutant and an inverse agonist for $5-\mathrm{HT}_{4} \mathrm{R}-\mathrm{T}^{104} \mathrm{~A}$ concerning $\mathrm{IP}_{1}$ production. Nevertheless, as recently highlighted by Tschammer et al (Tschammer et al., 2011) who found that a specific residue in the Dopamine $\mathrm{D}_{2 \mathrm{~L}}$ receptor is a major determinant of ligand-biased signaling, our analysis revealed that the $\mathrm{D}^{\infty}$ residue and to a lesser extent the $\mathrm{T}^{104}$ residue are crucial elements that have to be taken into account when designing new 5-HT ${ }_{4} \mathrm{R}$-biased ligands.

The most interesting finding of this study is the identification of two biased ligands (RS 67333 and prucalopride) for wild type $5-\mathrm{HT}_{4} \mathrm{R}$. Indeed, these two ligands acted as partial agonists for the $\mathrm{G}_{\mathrm{s}}$ pathway and as antagonists for the $\mathrm{G}_{\mathrm{q} / 11}$ pathway. Moreover, RS 67333 potently reversed BIMU8induced $\mathrm{IP}_{1}$ production. This drug has already been used in vivo to promote learning and memory in rodents, passes well through the blood brain barrier and has a good bioavailability (Freret et al., 2012; Marchetti et al., 2000; Marchetti et al., 2004). Therefore, RS 67333 could be an interesting tool for studying the effect of $\mathrm{G}_{\mathrm{s}}$ activation in vivo, while selectively blocking coupling of 5-HT $4 \mathrm{R}$ to $\mathrm{G}_{\mathrm{q} / 11}$. Multiple signaling pathways are linked to $5-\mathrm{HT}_{4} \mathrm{R}$ activation. This receptor is also coupled to $\mathrm{G}_{13}$ and RhoA activation and it has been involved in RhoA-dependent neurite retraction (Ponimaskin et al., 2002). Moreover, 5-HT $4 \mathrm{R}$ stimulates the extracellular signal-regulated kinase (ERK) pathway via Src activation and independently of $\mathrm{G}$ proteins or $\beta$-arrestins (Barthet et al., 2007). It would be interesting to study biased agonism of these additional pathways.

From a therapeutic point of view, $5-\mathrm{HT}_{4}$ agonists have been developed and commercialized for gastrointestinal disorders (cisapride, tegaserod, prucalopride, mosapride...). However, some were later withdrawn, as their administration was associated with cardiovascular or other adverse events. These side-effects could be ascribed to the lack of selectivity of the first commercialized drugs for $5-\mathrm{HT}_{4} \mathrm{R}$ and to their affinity also for other molecules, such as the hERG K${ }^{+}$channel and the 5-HT $\mathrm{HT}_{1}$ receptor (De Maeyer et al., 2008; Tack et al., 2012). Thus, highly specific synthetic agonists are urgently needed. Biased agonism and development of ligand-directed signaling can also help circumventing these adverse effects and thus it could be useful to have ligands that activate the $\mathrm{G}_{\mathrm{s}}$ pathway, without triggering $\mathrm{G}_{\mathrm{q} / 11}$ signaling. Indeed, cAMP production has been linked to neuroprotective effects 
(Michel and Agid, 1996; Silveira and Linden, 2006), whereas sustained $\mathrm{IP}_{3}$ production has been associated with tumor formation via PKC activation.

In conclusion, RS 67333 and prucalopride, which belong respectively to the aryl-ketone and benzofuran families, are two $5-\mathrm{HT}_{4} \mathrm{R}$ biased ligands that activate $\mathrm{G}_{\mathrm{s}}$ signaling and cAMP production, while blocking the $\mathrm{G}_{\mathrm{q} / 11}$ pathway and constitute promising tools for analyzing the role of $\mathrm{G}_{\mathrm{s}}$ activation in vivo. Moreover, this study provides important insights for designing new drugs that could be used to treat various disorders related to $5-\mathrm{HT}_{4} \mathrm{R}$ signaling (Bockaert et al., 2011).

\section{Experimental procedures}

\subsection{Plasmid Constructs}

Wild type 5-HT ${ }_{4(\mathrm{a})} \mathrm{R}, 5-\mathrm{HT}_{4} \mathrm{R}-\mathrm{D}^{100} \mathrm{~A}\left(\mathrm{D}^{100} \mathrm{~A}\right)$ and $5-\mathrm{HT}_{4} \mathrm{R}-\mathrm{T}^{104} \mathrm{~A}\left(\mathrm{~T}^{104} \mathrm{~A}\right)$ cDNA plasmids in pRK5 were previously described in (Barthet et al., 2005; Claeysen et al., 2003; Pellissier et al., 2009).

\subsection{Drugs}

The following compounds were used: BIMU8 (endo- $N$-(8-methyl-8-azabicyclo[3.2.1]oct-3-yl)-2-oxo3-isopropyl-2,3-dihydro-1 Hbenzimidazole-1-carboxamide), HTF- 919 (5-methoxy-indole-3carboxaldehyde 4-pentyl-iminosemicarbazone), (S)-zacopride ((S)-N-(1-azabicyclo[2.2.2]oct-3-yl)-4amino-5-chloro-2-methoxy-benzamide monohydrochloride), SC 53116 (4-Amino-5-chloro-N[[(1S,7aS)-hexahydro-1H-pyrrolizin-1-yl]methyl]-2-methoxy-benzamide), cisapride (cis- $N$-[1-[3-(4fluorophenoxy)propyl]-3-methoxy-4-piperidinyl]-4-amino-5-chloro-2-methoxy-benzamide, ML 10302 (2-(1-piperidinyl)ethyl-4-amino-5-chloro-2-methoxybenzoate), SL 65.0155 (5-(8-Amino-7-chloro-2,3dihydro-1,4-benzodioxin-5-yl)-3-[1-(2-phenylethyl)piperidin-4-yl]-1,3,4-oxadiazol-2(3H)-one hydrochloride), Prucalopride (4-Amino-5-chloro-N-[1-(3-methoxypropyl)piperidin-4-yl]-2,3dihydrobenzofuran-7-carboxamide), RS 67333 (1-(4-amino-5-chloro-2-methoxy-phenyl)-3-(1-butyl-4piperidinyl)-1-propanone), RS 56532 4-amino-4-chloro-N-(quinuclidin-3-yl)-1,8-naphthalimide, BIMU1 (3-ethyl-2,3-dihydro-N-[endo-8-methyl-8-azabicyclo(3.2.1)oct-3-yl]-2-oxo $\quad \begin{array}{lll}\text { H- } & \text { H }\end{array}$ benzimidazole-1-carboxamide, hydrochloride), GR 113308 (1-[2-(methylsulfonylamino)ethyl]-4piperidinyl 1-methyl-indole-3-carboxylate), Tropisetron (ICS 205 930; [(3a tropanyl)-1H-indole-3carboxylic acid ester]), GR 125487 ([1-[2(methylsulphonyl-amino)ethyl]4-piperidinyl]methyl-5fluoro-2-methoxy-1- $H$-indole-3-carboxylate, hydrochloride), SDZ 205557 (2-methoxy-4-amino-5chlorobenzoic acid 2-(diethylamino) ethyl ester, hydrochloride), ML 10375 (2-(cis-3,5-dimethyl-1piperidinyl)ethyl4-amino-5-chloro-2-methoxybenzoate), SB 204070 ((1-butyl-4-piperidinyl)methyl 8amino-7-chloro-1,4-benzodioxane-5-carboxylate), RS $39604 \quad$ (1-[4-amino-5-chloro-2-(3,5dimethoxybenzyl-oxy)phenyl]-3-[1-[2-[(methylsulfonyl)amino] ethyl]]-4-piperidinyl]]-1-propanone 
hydrochoride), Pimozide (2H-Benzimidazol-2-one, 1-(1-(4,4-bis(4-fluorophenyl)butyl)-4-piperidinyl)1,3-dihydro-), RO116-1148 2,3-dihydrobenzo-(1,4)-dioxine-5-carboxylic acid 1-butylpiperidin-4ylmethylamide hydrochloride.

\subsection{Cell Cultures and Transfections}

COS-7 cells were grown in Dulbecco's modified Eagle's medium (DMEM) supplemented with 10\% dialyzed fetal calf serum (dFCS) and antibiotics. Cells were transfected at $60-70 \%$ confluence by electroporation as described previously (Claeysen et al., 1999) and then processed for subsequent experiments.

\subsection{Determination of cAMP or Inositol Phosphate (IP $\left.{ }_{1}\right)$ production in transfected cells}

COS-7 cells were transfected with the appropriate plasmids and then seeded in 24-well plates (100 000 cells/well for cAMP and 500000 cells/well for $\mathrm{IP}_{1}$ measurement). Twenty-four hours after transfection, cells were incubated with the appropriate drug concentration for $10 \mathrm{~min}$ (cAMP) or 30 $\min \left(\mathrm{IP}_{1}\right)$, as previously described (Barthet et al., 2005). cAMP or $\mathrm{IP}_{1}$ accumulation was quantified by $\mathrm{HTRF}^{\circledR}$ using the cAMP Dynamic kit or the IP-One kit (Cisbio International, Bagnols-sur-Cèze, France), according to the manufacturer's instructions.

\subsection{Membrane preparation and radioligand binding assay}

Membranes were prepared from transiently transfected COS-7 cells plated in 15-cm dishes and grown in DMEM with 10\% dFCS as described in Claeysen et al. (Claeysen et al., 2003). Membranes were homogenized in $50 \mathrm{mM}$ HEPES (pH 7.4; $5 \mathrm{mg}$ of proteins in $1 \mathrm{ml}$ of solution) and stored at $-80^{\circ} \mathrm{C}$ until use. Membrane suspensions (about $10 \mu \mathrm{g}$ ), diluted in $100 \mu 1$ of $50 \mathrm{mM}$ HEPES containing 10 $\mathrm{mM}$ pargyline and $0.01 \%$ ascorbic acid, were incubated with $100 \mu \mathrm{l}\left[{ }^{3} \mathrm{H}\right]-\mathrm{GR} 113808$ (specific activity: $82 \mathrm{Ci} / \mathrm{mmol}$ ) and $50 \mu \mathrm{l}$ of buffer or competing drugs at $20^{\circ} \mathrm{C}$ for $30 \mathrm{~min}$. For saturation analysis assays, various concentrations of $\left[{ }^{3} \mathrm{H}\right]$-GR $113808(0.001-0.8 \mathrm{nM})$ were used. BIMU8 (10 $\mu \mathrm{M})$ was used to determine specific binding. To quantify [ $\left.{ }^{3} \mathrm{H}\right]$-GR 113808 bound to WT receptors in cells co-expressing WT and $\mathrm{D}^{100} \mathrm{~A}$ (or DD) $5-\mathrm{HT}_{4} \mathrm{Rs}$, experiments were performed in the presence of $10 \mu \mathrm{M} 5$-HT, which does not bind to the $\mathrm{D}^{100} \mathrm{~A}$ or DD mutants. The difference between the total $\left[{ }^{3} \mathrm{H}\right]-$ GR 113808 binding and the remaining binding measured in the presence of 5-HT corresponded to the $\left[{ }^{3} \mathrm{H}\right]$-GR 113808 binding to co-expressed $\mathrm{D}^{100} \mathrm{~A}$ (or DD) receptors. Protein concentration was determined using the bicinchoninic acidic method.

\subsection{Data Analysis}

The dose-response curves were fitted using GraphPad Prism and the following equation for monophasic dose-response curves: $\mathrm{y}=\left(\mathrm{y}_{\max }-\mathrm{y}_{\min }\right) / 1+\left[\left(\mathrm{x} / \mathrm{EC}_{50}\right) \mathrm{n}_{\mathrm{H}}\right]+\mathrm{y}_{\min }$, where $\mathrm{EC}_{50}$ is the concentration of the compound needed to obtain $50 \%$ of the maximal effect and $n_{H}$ is the Hill 
coefficient. Competition and saturation experiments were evaluated by non-linear regression analysis using GraphPad Prism. All represented data correspond to the mean \pm SEM of three independent experiments performed in triplicate. Statistical significance was determined with the Student Newman Keul's test using GraphPad Prism.

\section{ACKNOWLEDGMENTS}

We are grateful to Philippe Marin for constructive discussion and constant support. This work was financially supported by grants from CNRS, INSERM, the French Minister of Research (ANR Blanc 2006, to AD and SC), the France Alzheimer association (to SC), the Soroptimist International (French Union, to SC) and the Languedoc Roussillon region ("Chercheuse d'Avenir" 2012, to SC). Binding experiments, cAMP measurements and ELISA were carried out using the ARPEGE Pharmacology Screening Interactome facility at the Institute of Functional Genomics (Montpellier, France).

\section{REFERENCES}

Armbruster, B.N., Li, X., Pausch, M.H., Herlitze, S., Roth, B.L., 2007. Evolving the lock to fit the key to create a family of $\mathrm{G}$ protein-coupled receptors potently activated by an inert ligand. Proc Natl Acad Sci U S A. 104, 5163-8.

Barthet, G., Gaven, F., Framery, B., Shinjo, K., Nakamura, T., Claeysen, S., Bockaert, J., Dumuis, A., 2005. Uncoupling and endocytosis of 5-hydroxytryptamine 4 receptors. Distinct molecular events with different GRK2 requirements. J Biol Chem. 280, 27924-34.

Barthet, G., Framery, B., Gaven, F., Pellissier, L., Reiter, E., Claeysen, S., Bockaert, J., Dumuis, A., 2007. 5-hydroxytryptamine 4 receptor activation of the extracellular signal-regulated kinase pathway depends on Src activation but not on $\mathrm{G}$ protein or beta-arrestin signaling. Mol Biol Cell. 18, 1979-91.

Bockaert, J., Claeysen, S., Compan, V., Dumuis, A., 2011. 5-HT(4) receptors, a place in the sun: act two. Curr Opin Pharmacol. 11, 87-93.

Chang, W.C., Ng, J.K., Nguyen, T., Pellissier, L., Claeysen, S., Hsiao, E.C., Conklin, B.R., 2007. Modifying ligand-induced and constitutive signaling of the human 5-HT4 receptor. PLoS ONE. 2, e1317.

Claeysen, S., Sebben, M., Becamel, C., Bockaert, J., Dumuis, A., 1999. Novel brain-specific 5-HT4 receptor splice variants show marked constitutive activity: role of the $\mathrm{C}$-terminal intracellular domain. Mol. Pharmacol. 55, 910-920.

Claeysen, S., Joubert, L., Sebben, M., Bockaert, J., Dumuis, A., 2003. A Single Mutation in the 5-HT4 Receptor (5-HT4-R D100(3.32)A) Generates a Gs-coupled Receptor Activated Exclusively by Synthetic Ligands (RASSL). J Biol Chem. 278, 699-702.

Conklin, B.R., Hsiao, E.C., Claeysen, S., Dumuis, A., Srinivasan, S., Forsayeth, J.R., Guettier, J.M., Chang, W.C., Pei, Y., McCarthy, K.D., Nissenson, R.A., Wess, J., Bockaert, J., Roth, B.L., 2008. Engineering GPCR signaling pathways with RASSLs. Nat Methods. 5, 673-8. 
Coward, P., Wada, H.G., Falk, M.S., Chan, S.D., Meng, F., Akil, H., Conklin, B.R., 1998. Controlling signaling with a specifically designed Gi-coupled receptor. Proc Natl Acad Sci U S A. 95, 352-7.

De Maeyer, J.H., Lefebvre, R.A., Schuurkes, J.A., 2008. 5-HT4 receptor agonists: similar but not the same. Neurogastroenterol Motil. 20, 99-112.

Dong, S., Rogan, S.C., Roth, B.L., 2010. Directed molecular evolution of DREADDs: a generic approach to creating next-generation RASSLs. Nat Protoc. 5, 561-73.

Freret, T., Bouet, V., Quiedeville, A., Nee, G., Dallemagne, P., Rochais, C., Boulouard, M., 2012. Synergistic effect of acetylcholinesterase inhibition (donepezil) and 5-HT(4) receptor activation (RS67333) on object recognition in mice. Behav Brain Res. 230, 304-8.

Gesty-Palmer, D., Chen, M., Reiter, E., Ahn, S., Nelson, C.D., Wang, S., Eckhardt, A.E., Cowan, C.L., Spurney, R.F., Luttrell, L.M., Lefkowitz, R.J., 2006. Distinct beta-arrestin- and G protein-dependent pathways for parathyroid hormone receptor-stimulated ERK1/2 activation. J Biol Chem. 281, 10856-64.

Marchetti, E., Dumuis, A., Bockaert, J., Soumireu-Mourat, B., Roman, F.S., 2000. Differential modulation of the 5-HT(4) receptor agonists and antagonist on rat learning and memory. Neuropharmacology. 39, 2017-27.

Marchetti, E., Chaillan, F.A., Dumuis, A., Bockaert, J., Soumireu-Mourat, B., Roman, F.S., 2004. Modulation of memory processes and cellular excitability in the dentate gyrus of freely moving rats by a 5-HT4 receptors partial agonist, and an antagonist. Neuropharmacology. 47, 1021-35.

Michel, P.P., Agid, Y., 1996. Chronic activation of the cyclic AMP signaling pathway promotes development and long-term survival of mesencephalic dopaminergic neurons. J Neurochem. $67,1633-42$.

Nakajima, K., Wess, J., 2012. Design and functional characterization of a novel, arrestin-biased designer g protein-coupled receptor. Mol Pharmacol. 82, 575-82.

Pellissier, L.P., Sallander, J., Campillo, M., Gaven, F., Queffeulou, E., Pillot, M., Dumuis, A., Claeysen, S., Bockaert, J., Pardo, L., 2009. Conformational toggle switches implicated in basal constitutive and agonist-induced activated states of 5-hydroxytryptamine-4 receptors. Mol Pharmacol. 75, 982-90.

Ponimaskin, E.G., Profirovic, J., Vaiskunaite, R., Richter, D.W., Voyno-Yasenetskaya, T.A., 2002. 5hydroxytryptamine (4a) receptor is coupled to Ga subunit of heterotrimeric G13 protein. J Biol Chem. 28, 28.

Rajagopal, S., Rajagopal, K., Lefkowitz, R.J., 2010. Teaching old receptors new tricks: biasing seventransmembrane receptors. Nat Rev Drug Discov. 9, 373-86.

Scearce-Levie, K., Coward, P., Redfern, C.H., Conklin, B.R., 2001. Engineering receptors activated solely by synthetic ligands (RASSLs). Trends Pharmacol Sci. 22, 414-20.

Silveira, M.S., Linden, R., 2006. Neuroprotection by cAMP: Another brick in the wall. Adv Exp Med Biol. 557, 164-76.

Tack, J., Camilleri, M., Chang, L., Chey, W.D., Galligan, J.J., Lacy, B.E., Muller-Lissner, S., Quigley, E.M., Schuurkes, J., De Maeyer, J.H., Stanghellini, V., 2012. Systematic review: cardiovascular safety profile of 5-HT(4) agonists developed for gastrointestinal disorders. Aliment Pharmacol Ther. 35, 745-67.

Thomsen, A.R., Hvidtfeldt, M., Brauner-Osborne, H., 2012. Biased agonism of the calcium-sensing receptor. Cell Calcium. 51, 107-16.

Tschammer, N., Bollinger, S., Kenakin, T., Gmeiner, P., 2011. Histidine 6.55 is a major determinant of ligand-biased signaling in dopamine D2L receptor. Mol Pharmacol. 79, 575-85.

Wei, H., Ahn, S., Shenoy, S.K., Karnik, S.S., Hunyady, L., Luttrell, L.M., Lefkowitz, R.J., 2003. Independent beta-arrestin 2 and $\mathrm{G}$ protein-mediated pathways for angiotensin II activation of extracellular signal-regulated kinases 1 and 2. Proc Natl Acad Sci U S A. 100, 10782-7. 
Table 1

\begin{tabular}{|c|c|c|c|c|c|c|}
\hline \multirow[t]{3}{*}{ Drug $(10 \mu M)$} & \multicolumn{6}{|c|}{ cAMP } \\
\hline & \multicolumn{2}{|c|}{ WT 5-HT,R } & \multicolumn{2}{|c|}{ 5-HT,R-D ${ }^{100} A$} & \multicolumn{2}{|c|}{ 5-HT,R-T ${ }^{104} A$} \\
\hline & $\begin{array}{c}\mathbf{R}_{\max } \pm \\
\text { S.E.M. } \\
(\%)\end{array}$ & $\mathbf{E C}_{50}$ & $\begin{array}{c}R_{\max } \pm \\
\text { S.E.M. } \\
(\%)\end{array}$ & $\mathrm{EC}_{50}$ & $\begin{array}{c}\mathbf{R}_{\max } \pm \\
\text { S.E.M. } \\
(\%)\end{array}$ & $\mathbf{E C}_{50}$ \\
\hline Serotonin $(5-\mathrm{HT})$ & $88 \pm 5$ & $4.2 \pm 0.8 \times 10^{-9}$ & - & $1.9 \pm 0.9 \times 10^{-6}$ & $107 \pm 4$ & $7.0 \pm 1.2 \times 10^{-8}$ \\
\hline BIMU8 & 100 & $1.9 \pm 0.3 \times 10^{-8}$ & 100 & $6.3 \pm 0.5 \times 10^{-9}$ & 100 & $8.5 \pm 0.6 \times 10^{-8}$ \\
\hline \multicolumn{7}{|l|}{ AGONISTS } \\
\hline \multicolumn{7}{|l|}{$\begin{array}{l}\text { Indoles and Indole } \\
\text { Carboxylates }\end{array}$} \\
\hline HTF919 & $65 \pm 5$ & $5.0 \pm 0.4 \times 10^{-9}$ & $20 \pm 3$ & $1.0 \pm 0.2 \times 10^{-6}$ & $57 \pm 5$ & $1.2 \pm 0.2 \times 10^{-7}$ \\
\hline \multicolumn{7}{|l|}{ Benzamides } \\
\hline Zacopride & $91 \pm 4$ & $1.6 \pm 0.4 \times 10^{-7}$ & $75 \pm 4$ & $2.1 \pm 0.8 \times 10^{-7}$ & $8 \pm 3$ & $2.9 \pm 0.9 \times 10^{-5}$ \\
\hline SC 53116 & $72 \pm 3$ & & $85 \pm 4$ & & $35 \pm 4$ & \\
\hline Cisapride & $61 \pm 3$ & $7.8 \pm 1.2 \times 10^{-9}$ & $72 \pm 5$ & $7.4 \pm 0.5 \times 10^{-9}$ & $21 \pm 2$ & $2.0 \pm 0.6 \times 10^{-6}$ \\
\hline \multicolumn{7}{|l|}{ Benzoates } \\
\hline ML10302 & $34 \pm 3$ & $1.4 \pm 0.2 \times 10^{-9}$ & $60 \pm 2$ & $7.7 \pm 1.0 \times 10^{-9}$ & - & N.D. \\
\hline \multicolumn{7}{|l|}{ Benzodioxanes } \\
\hline SL 65.0155 & $22 \pm 3$ & N.D. & $58 \pm 4$ & N.D. & $9 \pm 2$ & N.D. N.D. \\
\hline \multicolumn{7}{|l|}{ Benzofurans } \\
\hline Prucalopride & $50 \pm 7$ & $2.1 \pm 0.8 \times 10^{-8}$ & $83 \pm 6$ & $5.3 \pm 1.1 \times 10^{-8}$ & $28 \pm 1$ & $1.0 \pm 0.5 \times 10^{-6}$ \\
\hline \multicolumn{7}{|l|}{ Aryl ketones } \\
\hline RS 67333 & $49 \pm 2$ & $8.4 \pm 1.1 \times 10^{-10}$ & $90 \pm 6$ & $1.2 \pm 0.6 \times 10^{-9}$ & - & N.D. \\
\hline \multicolumn{7}{|l|}{ Naphtalimides } \\
\hline RS 56532 & $58 \pm 3$ & $1.4 \pm 0.3 \times 10^{-7}$ & $68 \pm 3$ & $1.9 \pm 0.5 \times 10^{-7}$ & $20 \pm 5$ & $1.2 \pm 0.7 \times 10^{-5}$ \\
\hline \multicolumn{7}{|l|}{ Benzimidazolones } \\
\hline BIMU1 & $64 \pm 5$ & N.D. & $79 \pm 5$ & N.D. & $63 \pm 4$ & N.D. \\
\hline
\end{tabular}


Table 2

\begin{tabular}{|c|c|c|c|}
\hline \multirow[t]{3}{*}{ Drug $(10 \mu \mathrm{M})$} & \multicolumn{3}{|c|}{ сAMP } \\
\hline & WT 5-HT,R & 5-HT,R-D ${ }^{100} A$ & 5-HTR-T ${ }^{104} A$ \\
\hline & $\begin{array}{c}\mathbf{R}_{\max } \pm \text { S.E.M. } \\
(\%)\end{array}$ & $\begin{array}{c}\mathbf{R}_{\max } \pm \text { S.E.M. } \\
(\%)\end{array}$ & $\begin{array}{c}R_{\max } \pm \text { S.E.M. } \\
(\%)\end{array}$ \\
\hline Serotonin $(5-\mathrm{HT})$ & $88 \pm 5$ & - & $107 \pm 4$ \\
\hline BIMU8 & 100 & 100 & 100 \\
\hline
\end{tabular}

\section{ANTAGONISTS \\ Indoles and Indole}

Carboxylates

GR 113808

Tropisetron

GR 125487

$\begin{array}{cc}- & 50 \pm 4 \\ 23 \pm 2 & 51 \pm 5 \\ - & 36 \pm 5 \\ - & 13 \pm 3\end{array}$

$7 \pm 2$

$38 \pm 4$

Pimozide

$36 \pm 5$

Benzamides

SDZ 205557

$22 \pm 5$

$70 \pm 3$

\section{Benzoates}

ML 10375

$9 \pm 3$

$72 \pm 2$

Benzoate dioxanes

SB 204070

$29 \pm 4$

$88 \pm 3$

$8 \pm 2$

Benzoate Aryl Ketones

$\begin{array}{llcc}\text { RS } 39604 & 19 \pm 3 & 77 \pm 5 & - \\ \text { RS } 100235 & 20 \pm 2 & 56 \pm 4 & 11 \pm 3 \\ \text { RS } 67532 & 25 \pm 2 & 91 \pm 6 & 13 \pm 2\end{array}$

INVERSE AGONISTS

Benzoate dioxanes

RO 1162617

RO 1161148

$-$

$5 \pm 3$

$6 \pm 2$ 
Table 3

\begin{tabular}{|c|c|c|c|c|c|c|}
\hline \multirow[t]{3}{*}{ Drug $(10 \mu M)$} & \multicolumn{6}{|c|}{$\mathbf{I P}_{\mathbf{1}}$} \\
\hline & \multicolumn{2}{|c|}{ WT 5-HTA } & \multicolumn{2}{|c|}{ 5-HT R-D ${ }^{100} A$} & \multicolumn{2}{|c|}{ 5-HT,R-T ${ }^{104} A$} \\
\hline & $\begin{array}{c}\mathbf{R}_{\max } \pm \\
\text { S.E.M. } \\
(\%)\end{array}$ & $\mathrm{EC}_{50}$ & $\begin{array}{c}\mathbf{R}_{\max } \pm \\
\text { S.E.M. } \\
(\%)\end{array}$ & $\mathrm{EC}_{50}$ & $\begin{array}{c}\mathbf{R}_{\max } \pm \\
\text { S.E.M. } \\
(\%)\end{array}$ & $\mathrm{EC}_{50}$ \\
\hline Serotonin $(5-\mathrm{HT})$ & $82 \pm 7$ & $1.9 \pm 0.3 \times 10^{-7}$ & - & $6.2 \pm 0.2 \times 10^{-10}$ & $60 \pm 7$ & $1.2 \pm 0.9 \times 10^{-5}$ \\
\hline BIMU8 & 100 & $7.8 \pm 1.0 \times 10^{-8}$ & 100 & $2.3 \pm 0.9 \times 10^{-8}$ & 100 & $6.7 \pm 0.6 \times 10^{-7}$ \\
\hline \multicolumn{7}{|l|}{ AGONISTS } \\
\hline \multicolumn{7}{|c|}{$\begin{array}{l}\text { Indoles and Indole } \\
\text { Carboxylates }\end{array}$} \\
\hline HTF919 & $73 \pm 4$ & $6.9 \pm 0.3 \times 10^{-8}$ & - & N.D. & $10 \pm 4$ & $1.9 \pm 0.7 \times 10^{-5}$ \\
\hline \multicolumn{7}{|l|}{ Benzamides } \\
\hline Zacopride & $25 \pm 3$ & $1.4 \pm 0.8 \times 10^{-6}$ & $71 \pm 4$ & $5.4 \pm 1.0 \times 10^{-7}$ & $3 \pm 2$ & N.D. \\
\hline Cisapride & - & N.D. & $97 \pm 2$ & $2.0 \pm 0.3 \times 10^{-7}$ & $14 \pm 3$ & $1.6 \pm 0.5 \times 10^{-5}$ \\
\hline \multicolumn{7}{|l|}{ Benzoates } \\
\hline ML10302 & - & N.D. & $50 \pm 4$ & $1.3 \pm 0.6 \times 10^{-7}$ & - & N.D. \\
\hline \multicolumn{7}{|l|}{ Benzofurans } \\
\hline Prucalopride & - & N.D. & $70 \pm 4$ & $4.7 \pm 0.6 \times 10^{-7}$ & - & N.D. \\
\hline \multicolumn{7}{|l|}{ Aryl ketones } \\
\hline RS 67333 & $19 \pm 1$ & $2.0 \pm 0.7 \times 10^{-7}$ & $38 \pm 3$ & $7.3 \pm 0.7 \times 10^{-8}$ & $14 \pm 2$ & $2,3 \pm 1.1 \times 10^{-6}$ \\
\hline \multicolumn{7}{|l|}{ Naphtalimides } \\
\hline RS 56532 & $17 \pm 6$ & $2.4 \pm 0.2 \times 10^{-5}$ & $59 \pm 3$ & $1.1 \pm 0.4 \times 10^{-6}$ & $22 \pm 4$ & $4.3 \pm 0.7 \times 10^{-6}$ \\
\hline
\end{tabular}




\section{TABLE LEGENDS}

Table 1: Agonist potencies $\left(E C_{50}\right)$ and maximal response $\left(R_{\max }\right)$ above basal of the tested 5-HT, $R$ "agonists" with WT 5-HT 4 R, 5-HT 4 R-D ${ }^{\cdots 0} \mathrm{~A}$ and 5-HT ${ }_{4} \mathrm{R}-\mathrm{T}^{\mathbf{1 0 4}} \mathrm{A}$ concerning cAMP accumulation. $\mathrm{EC}_{50}$ and $\mathrm{R}_{\max }$ for cAMP accumulation in COS-7 cells that were transiently transfected with the different 5-HT $\mathrm{R}$ plasmids (50 ng) following incubation with $5-\mathrm{HT}_{4} \mathrm{R}$ "agonists" $(10 \mu \mathrm{M}$ for 10 minutes). $\mathrm{R}_{\max }$ was calculated by removing the basal response and is expressed as a percentage of the BIMU8 maximal response $(6.7 \pm 0.3 \mathrm{pmol}$ of cAMP/100,000 cells for WT 5 -HT $\mathrm{R}, 5.0 \pm 0.2 \mathrm{pmol}$ for 5-HT ${ }_{4} \mathrm{R}-\mathrm{D}^{\infty} \mathrm{A}$ and $4.4 \pm 0.3 \mathrm{pmol}$ for $5-\mathrm{HT}_{4} \mathrm{R}-\mathrm{T}^{104} \mathrm{~A}$ ). -, no significant effect above basal. Data represent the mean \pm SEM of at least three independent experiments performed in triplicate.

Table 2: Maximal response $\left(R_{\max }\right)$ above basal of the tested 5-HT, $R$ "antagonists" and "inverse agonists" with WT 5-HT 4 R, 5-HT 4 R-D ${ }^{i \infty}$ or $5-H_{T} T_{4} R-T^{104} A$ concerning cAMP accumulation.

$\mathrm{R}_{\max }$ for cAMP accumulation in COS-7 cells that were transiently transfected with the different 5$\mathrm{HT}_{4} \mathrm{R}$ plasmids (50 ng) following incubation with 5-HT $\mathrm{R}$ "antagonists" and "inverse agonists" $(10 \mu \mathrm{M}$ for 10 minutes). $R_{\max }$ was calculated by subtracting the basal response and is expressed as a percentage of the BIMU8 maximal response $(6.7 \pm 0.3 \mathrm{pmol}$ of cAMP/100,000 cells for WT 5 -HT $\mathrm{R}, 5.0 \pm 0.2$ pmol for 5 -HT R-D ${ }^{\circ \circ} \mathrm{A}$ and $4.4 \pm 0.3$ pmol for 5 -HTR- $\mathrm{T}^{104} \mathrm{~A}$ ). -, no significant effect above basal. --, inverse agonist effect. Data represent the mean \pm SEM of at least three independent experiments performed in triplicate.

Table 3: Agonist potencies $\left(E C_{50}\right)$ and maximal response $\left(R_{\max }\right)$ above basal of the tested 5-HT $R$ ligands with WT 5-HT ${ }_{4} \mathrm{R}, 5-\mathrm{HT}_{4} \mathrm{R}-\mathrm{D}^{\text {wo }} \mathrm{A}$ or $5-\mathrm{HT}_{4} \mathrm{R}-\mathrm{T}^{104} \mathrm{~A}$ concerning $\mathrm{IP}_{1}$ accumulation.

$\mathrm{EC}_{50}$ and $\mathrm{R}_{\max }$ for $\mathrm{IP}_{1}$ accumulation in COS-7 cells that were transiently transfected with the different 5 -HT $\mathrm{R}$ plasmids (100 ng) following incubation with $5-\mathrm{HT}_{4} \mathrm{R}$ ligands $\left(10 \mu \mathrm{M}\right.$ for 30 minutes). $\mathrm{R}_{\max }$ was calculated by removing the basal response and is expressed as a percentage of the BIMU8 maximal response $\left(53.8 \pm 6.0 \mathrm{pmol}\right.$ of $\mathrm{IP}_{1} / 250,000$ cells for WT $5-\mathrm{HT}_{4} \mathrm{R}, 42.7 \pm 6.9 \mathrm{pmol}$ for $5-\mathrm{HT}_{4} \mathrm{R}-\mathrm{D}^{\infty} \mathrm{A}$ and $40.8 \pm 4.2$ pmol for $5-\mathrm{HT}_{4} \mathrm{R}-\mathrm{T}^{104} \mathrm{~A}$ ). Data represent the mean $\pm \mathrm{SEM}$ of at least three independent experiments performed in triplicate. 


\section{FIGURE LEGENDS}

Figure 1: Dose-response curves of $\mathrm{IP}_{1}$ accumulation following incubation with 5-HT, $R$ ligands. COS-7 cells that transiently express WT 5-HT 4 R (A, B), 5-HT 4 R-D ${ }^{\infty} \mathrm{A}(\mathrm{C}, \mathrm{D})$ or $5-\mathrm{HT}_{4} \mathrm{R}-\mathrm{T}^{104} \mathrm{~A}(\mathrm{E}, \mathrm{F})$ were incubated with the different $5-\mathrm{HT}_{4} \mathrm{R}$ ligands and $\mathrm{IP}_{1}$ accumulation was expressed as the percentage of the $\mathrm{IP}_{1}$ production $(60.5 \pm 2.6 \mathrm{pmol} / 100,000$ cells $)$ induced by $10^{-5} \mathrm{M} 5$-HT in cells transfected with $100 \mathrm{ng}$ of WT $5-\mathrm{HT}_{4} \mathrm{R}$ plasmid (A, B, E, F) or as a percentage of the $\mathrm{IP}_{1}$ production $\left(49.6 \pm 2.2 \mathrm{pmol} / 250,000\right.$ cells) induced by $10^{-5} \mathrm{M}$ BIMU8 in cells transfected with $100 \mathrm{ng}$ of $5-\mathrm{HT}_{4} \mathrm{R}-$ $\mathrm{D}^{\infty \mathrm{A}} \mathrm{A}$ plasmid $(\mathrm{C}, \mathrm{D})$. Data for each drug correspond to the mean \pm SEM of three independent experiments performed in triplicate.

\section{Figure 2: Characterization of biased 5-HT 4 R ligands.}

COS-7 cells that transiently express WT 5- $\mathrm{HT}_{4} \mathrm{R}$ were incubated with the indicated ligands. (A-C) Dose-response curves for cAMP and $\mathrm{IP}_{1}$ accumulation. cAMP and $\mathrm{IP}_{1}$ values were expressed as a percentage of the cAMP or $\mathrm{IP}_{1}$ production $(6.7 \pm 0.3 \mathrm{pmol} / 100,000$ cells or $53.8 \pm 6.0 \mathrm{pmol} / 250,000$ cells, respectively) induced by $10^{-5} \mathrm{M}$ BIMU8 in cells transfected with $50 \mathrm{ng}$ (cAMP) or $100 \mathrm{ng}\left(\mathrm{IP}_{1}\right)$ WT 5-HT ${ }_{4} \mathrm{R}$ plasmid. (D) Competition of BIMU8-induced $\mathrm{IP}_{1}$ response. $\mathrm{IP}_{1}$ values were expressed as a percentage of the $\mathrm{IP}_{1}$ production $(42.2 \pm 3.7 \mathrm{pmol} / 250,000$ cells $)$ induced by $10^{-5} \mathrm{M}$ BIMU8 in cells transfected with $100 \mathrm{ng}$ WT $5-\mathrm{HT}_{4} \mathrm{R}$ plasmid. Each point in the curve is the mean \pm SEM of three independent experiments performed in triplicate. 
A

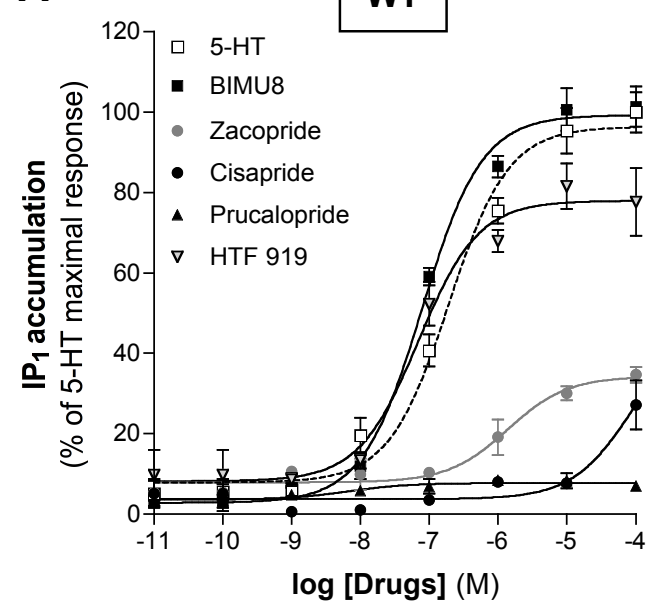

C

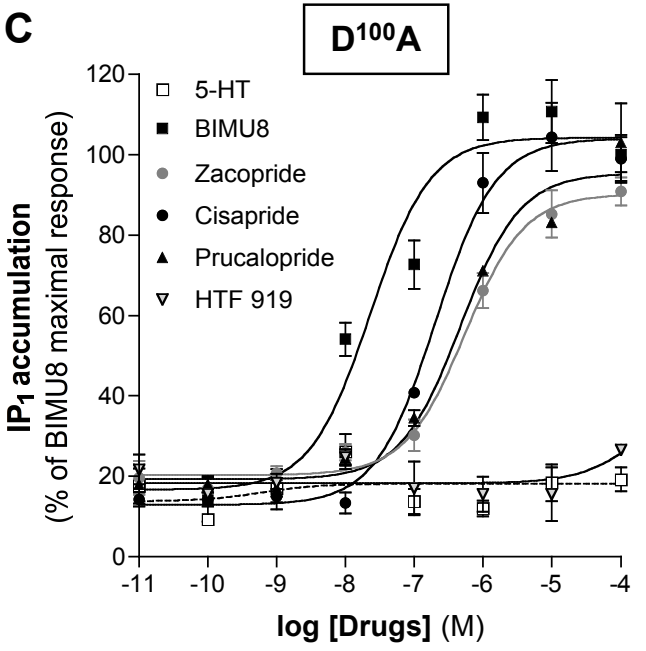

E

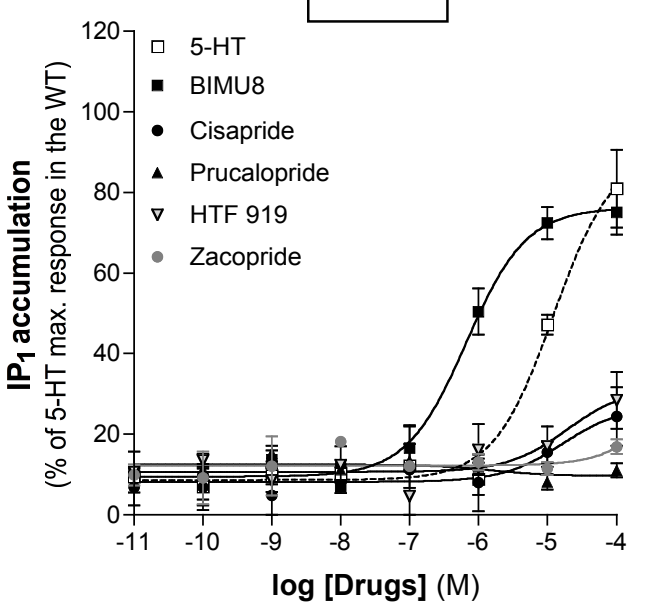

B

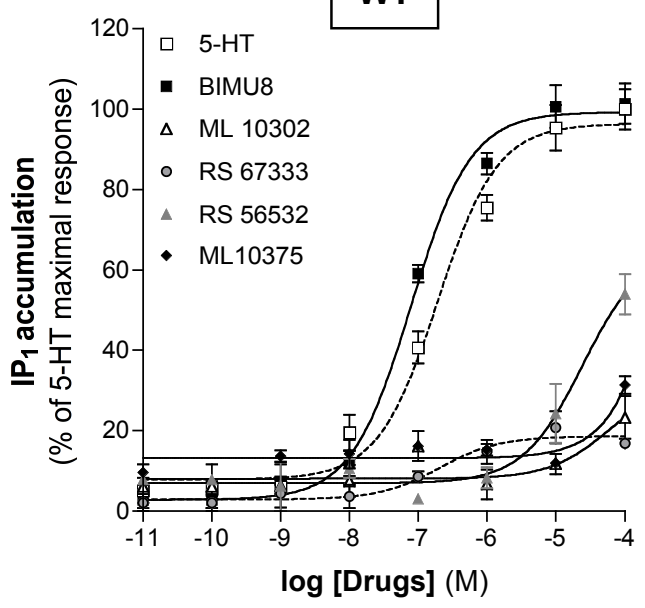

D

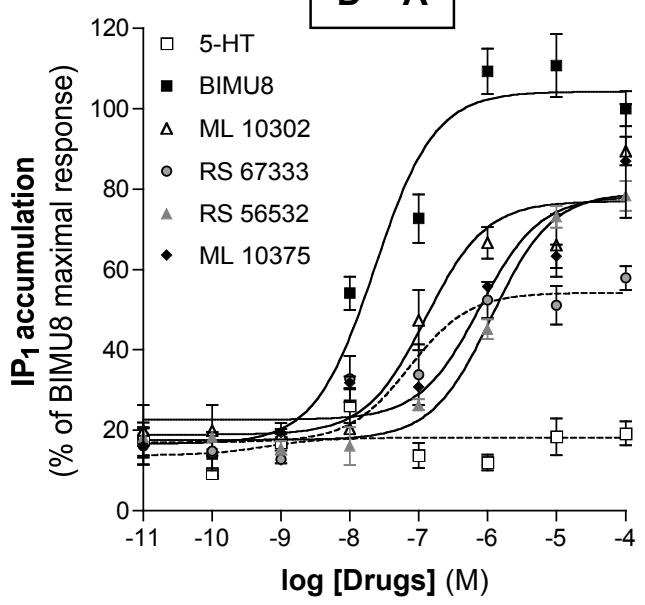

F

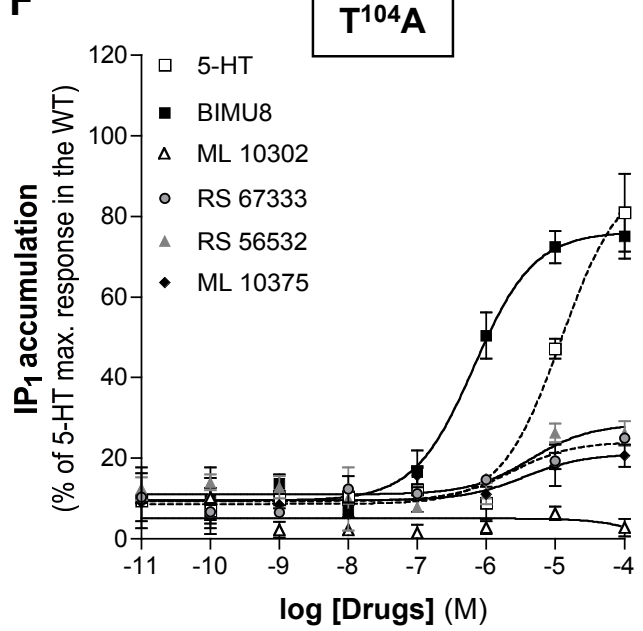


A

\section{CAMP}
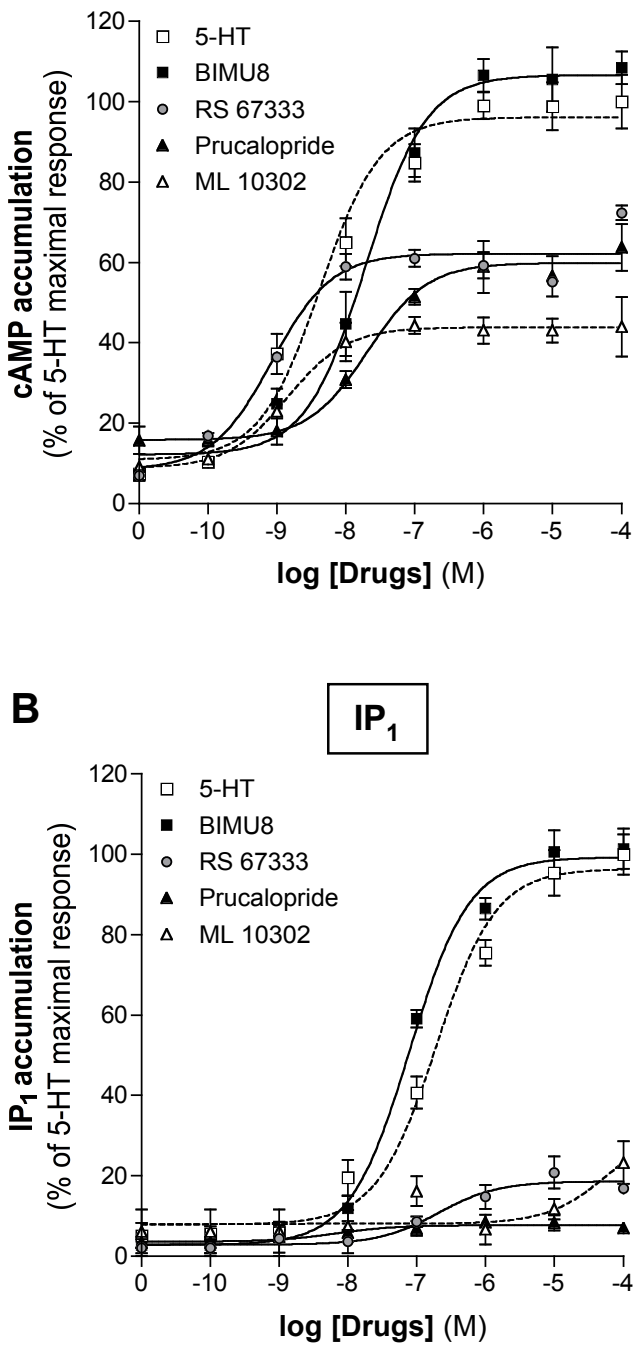

C cAMP \& $\mathbb{I P}_{1}$
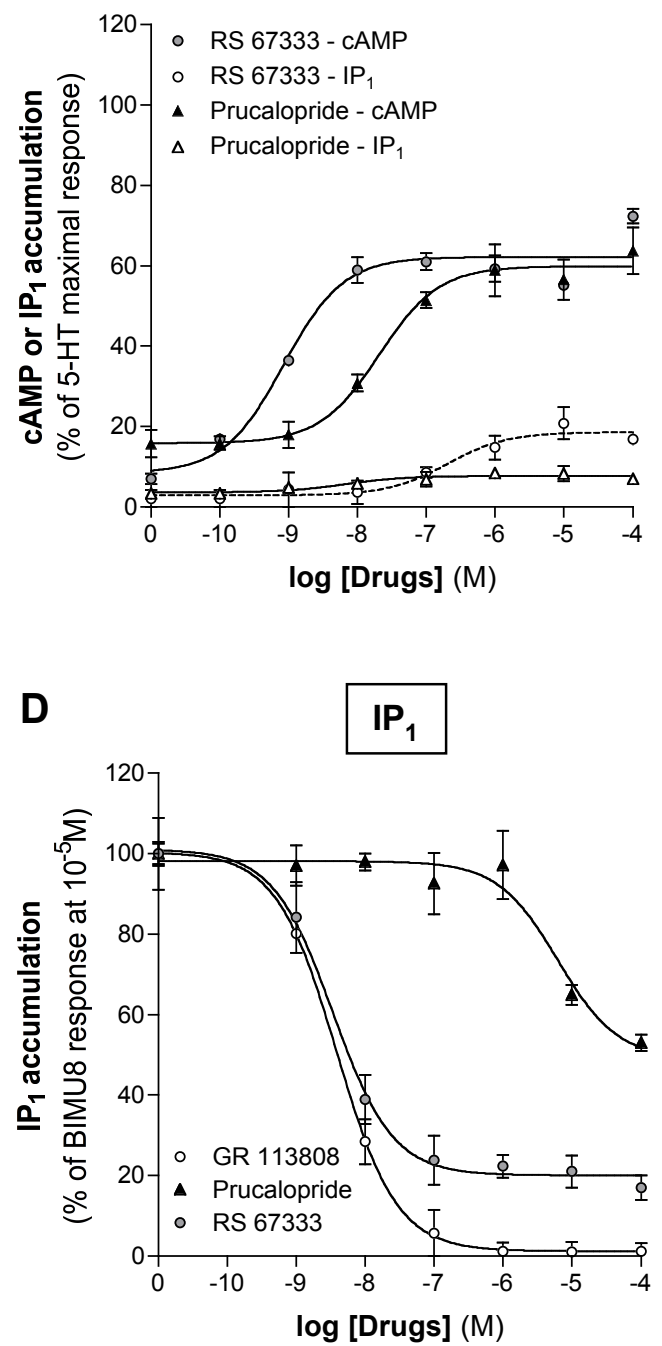


\title{
PHARMACOLOGICAL PROFILE OF ENGINEERED 5-HT 4 RECEPTORS AND IDENTIFICATION OF 5-HT 4 RECEPTOR-BIASED LIGANDS
}

\author{
Florence Gaven, Lucie P. Pellissier, Emilie Queffeulou, Maud Cochet, Joël Bockaert, \\ Aline Dumuis and Sylvie Claeysen
}

\author{
CONTENTS:
}

\section{Supplemental Figure 1: 5-HT $\mathrm{R}$ ligand-mediated cAMP and $\mathrm{IP}_{1}$ maximal responses.}

COS-7 cells were transiently transfected with the WT 5- $\mathrm{HT}_{4} \mathrm{R}(\mathrm{A}, \mathrm{B}), 5-\mathrm{HT}_{4} \mathrm{R}-\mathrm{D}^{100} \mathrm{~A}(\mathrm{C}, \mathrm{D})$ or $5-\mathrm{HT}_{4} \mathrm{R}-$ $\mathrm{T}^{104} \mathrm{~A}$ constructs and then (A-B) cAMP accumulation was quantified following incubation with $10^{-5} \mathrm{M}$ of each 5- $\mathrm{HT}_{4} \mathrm{R}$ ligand. Values are expressed as a percentage of the cAMP production $(6.7 \pm 0.3$ $\mathrm{pmol} / 100,000$ cells for WT $5-\mathrm{HT}_{4} \mathrm{R}, 5.0 \pm 0.2 \mathrm{pmol}$ for $5-\mathrm{HT}_{4} \mathrm{R}-\mathrm{D}^{100} \mathrm{~A}$ and $4.4 \pm 0.3$ pmol for $5-\mathrm{HT}_{4} \mathrm{R}-$ $\mathrm{T}^{104} \mathrm{~A}$ ) induced by $10^{-5} \mathrm{M}$ BIMU8 in cells transfected with $100 \mathrm{ng}$ of WT $5-\mathrm{HT}_{4} \mathrm{R}$ plasmid. (C) $\mathrm{IP}_{1}$ accumulation induced by incubation with $10^{-4} \mathrm{M}$ ligands. Values are expressed as a percentage of the IP ${ }_{1}$ production $\left(53.8 \pm 6.0 \mathrm{pmol}\right.$ of IP1/250,000 cells for WT $5-\mathrm{HT}_{4} \mathrm{R}, 42.7 \pm 6.9 \mathrm{pmol}$ for $5-\mathrm{HT}_{4} \mathrm{R}-\mathrm{D}^{100} \mathrm{~A}$ and $40.8 \pm 4.2$ pmol for $5-\mathrm{HT}_{4} \mathrm{R}-\mathrm{T}^{104} \mathrm{~A}$ D100A and T104A) induced by $10^{-4} \mathrm{M}$ BIMU8 in cells transfected with $100 \mathrm{ng}$ of WT $5-\mathrm{HT}_{4} \mathrm{R}$ plasmid. Data for each drug correspond to the mean \pm SEM of three independent experiments performed in triplicate. 


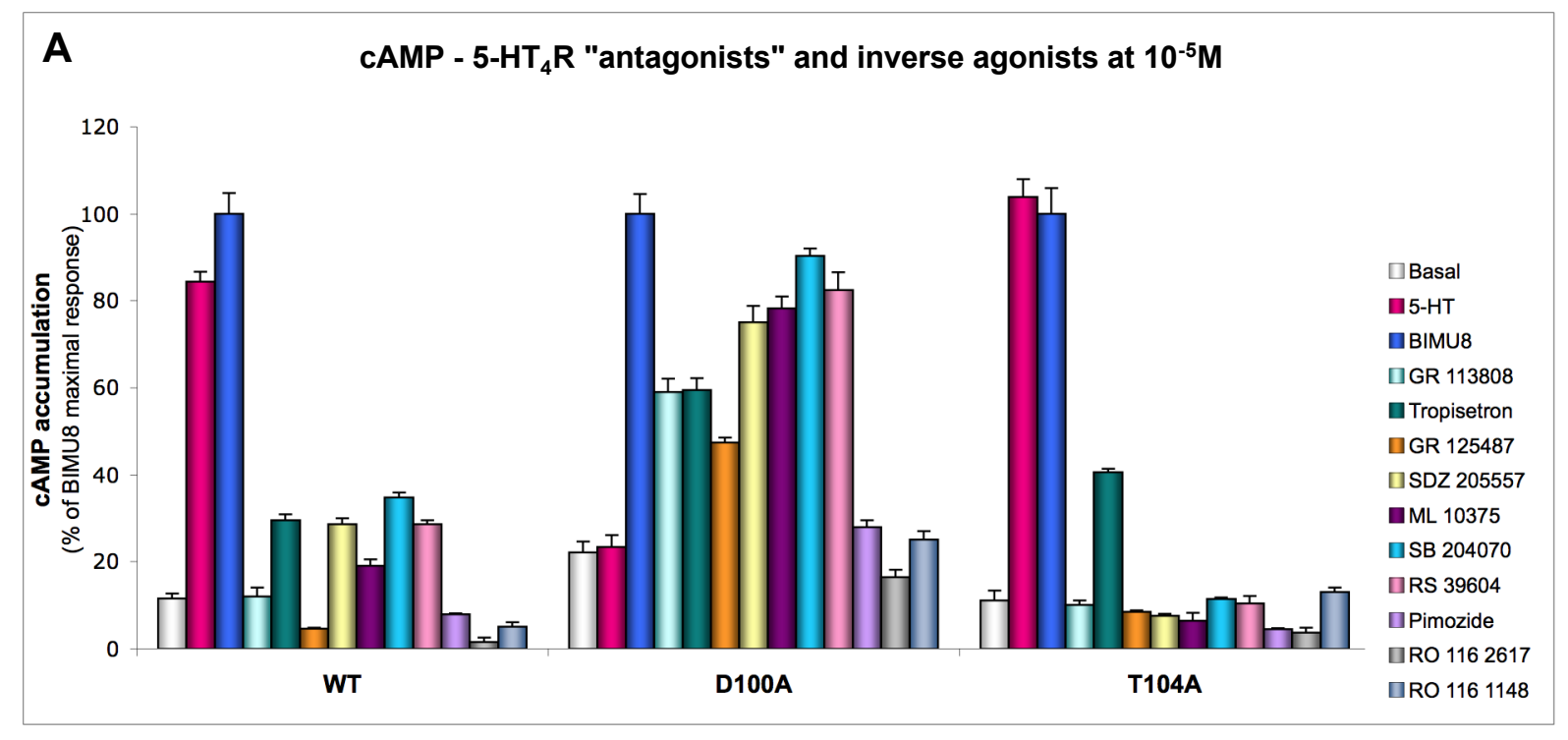

B

cAMP - 5- $\mathrm{HT}_{4} \mathrm{R}$ "agonists" at $10^{-5} \mathrm{M}$

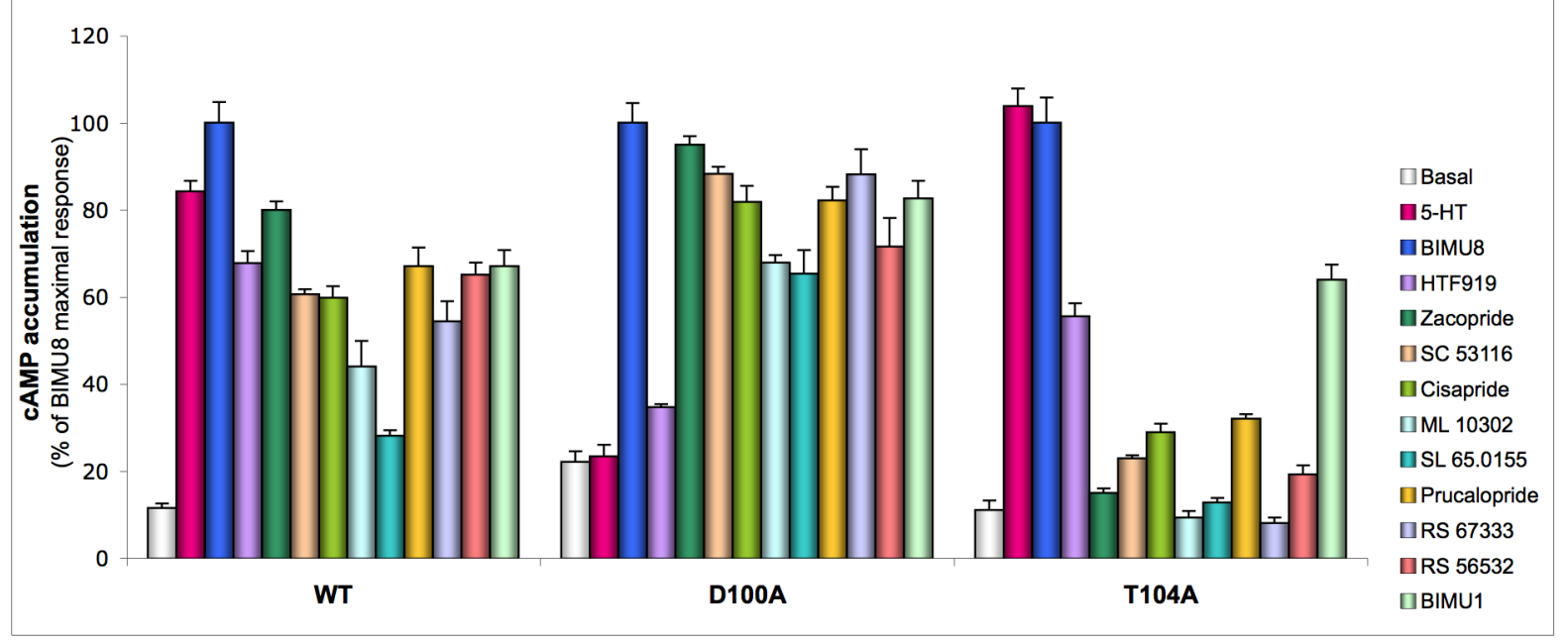

C

$\mathrm{IP}_{1}-\mathbf{5 - H T} \mathrm{H}_{4} \mathrm{R}$ ligands at $10^{-4} \mathrm{M}$

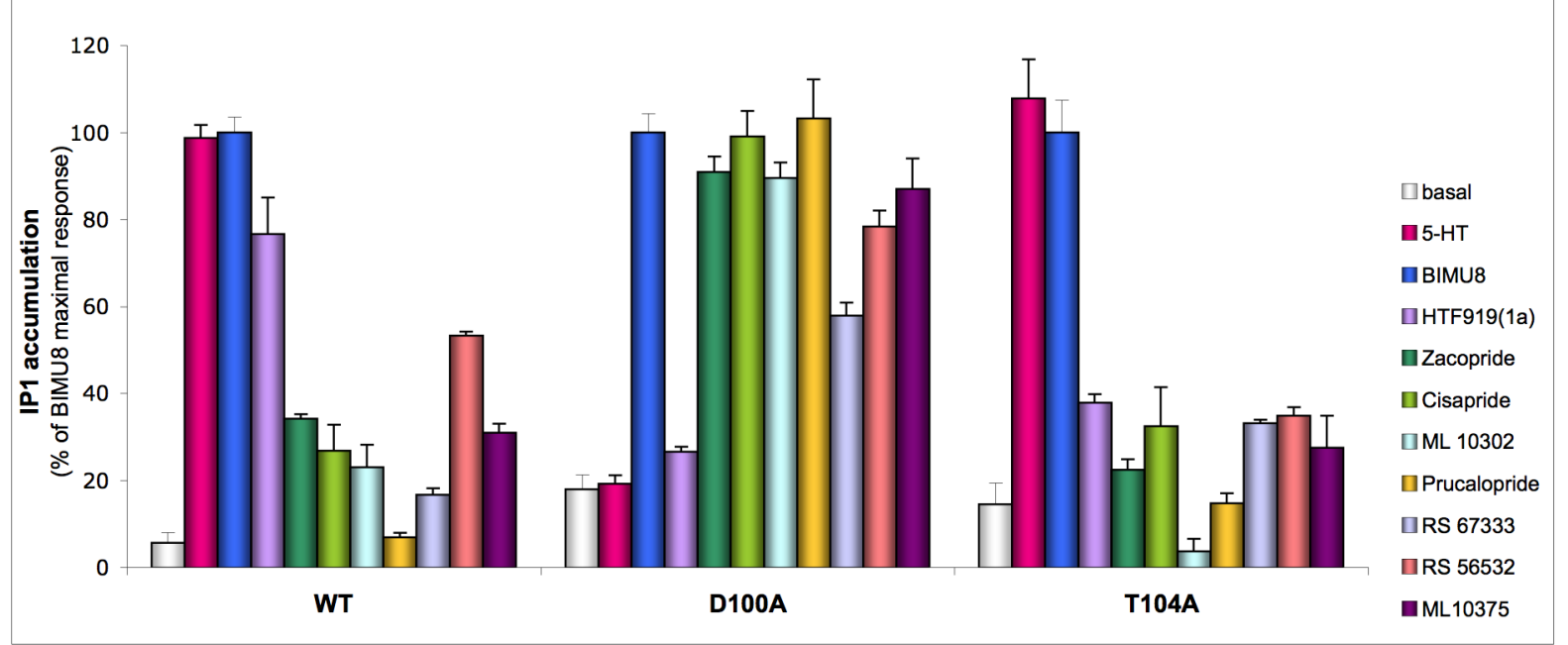




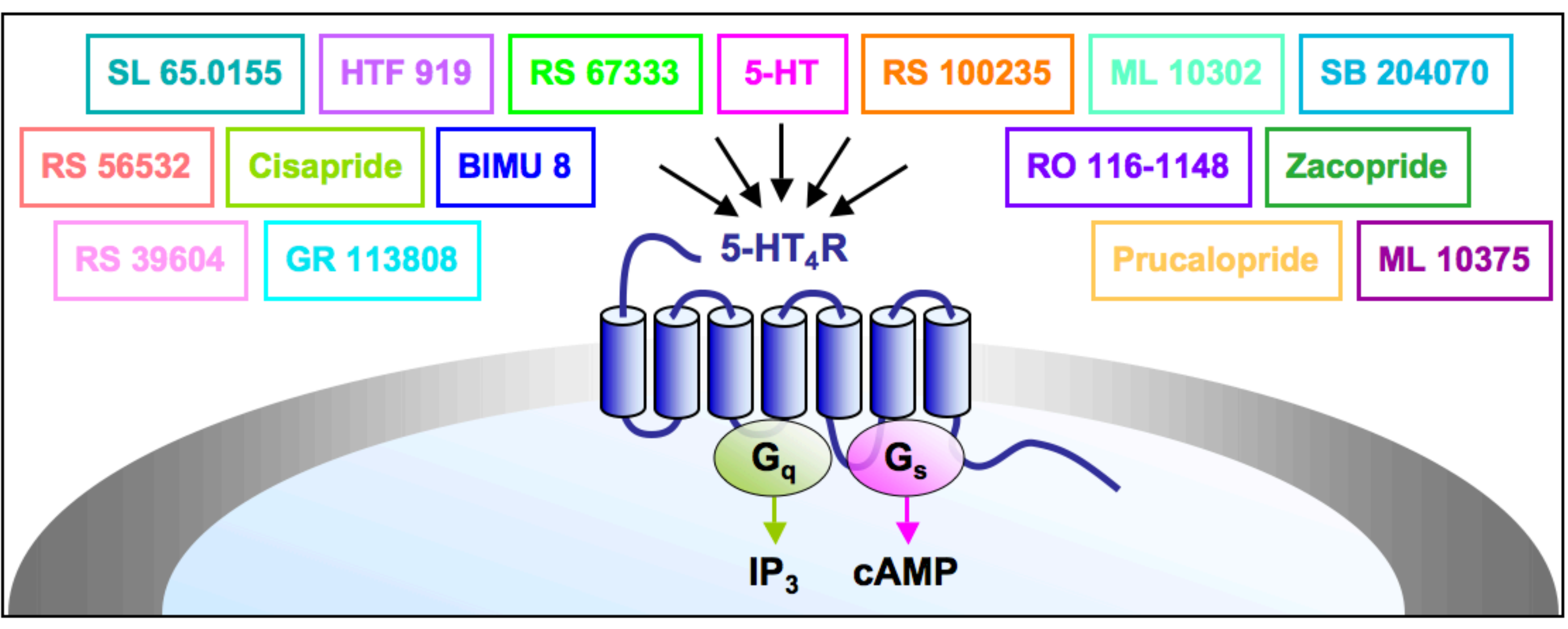

